\title{
CHAPTER 20 \\ Faith in God and the Health of People
}

\author{
Leith Anderson
}

Summary Engaging religious groups in environmental stewardship for human health begins with their theological presuppositions and is most persuasive when influenced by those leaders who share their faith.

Faith in God and the health of people are universal. Eighty-four percent of the world's 7.3 billion people are affiliated with some religion (Christians 31.2\%; Muslims 24.1\%; unaffiliated 16\%; Hindus 15.1\%; Buddhists $6.9 \%$; folk religions 5.7\%; other religions 0.8\%; Jews 0.2\%) (Hackett \& McClendon, 2017). While not everyone in the world is religious, about eight in ten are religious and the rest are affected by the religious beliefs of the many around them. However, the health of humans involves everyone. One hundred percent of the world's population are somewhere on the continuum of good health to poor health.

While religion and health usually are studied under different academic disciplines, practical experience combines them in most lives. As Pope Francis asserted in Laudato Si', "everything is interrelated" (Catholic Ecology, 2015). We cannot conflate religion and human health, but we can seek to connect them. It is a challenging task because there is generally greater consensus on health than on religion. Moreover, there are different starting points. In broad terms, religion tends to start with God and faith, while science starts with research and predictability. That said, Christians are more likely to begin with God and move on to health and the environment, while "some non-Western religious traditions, like Hinduism, make a tighter link between representations of the divine and nature" (Ecklund \& Scheitle, 2018).

L. Anderson ( $\square)$

National Association of Evangelicals, Washington, DC, USA

e-mail: leith.anderson@wooddale.org 


\section{The Protestant Evangelical Perspective}

As an American Protestant Evangelical Christian, my perspective is rooted in one segment of Christian faith and one nation's current engagement in the "Health of People, Health of Planet and Our Responsibility" (Pontifical Academy of Sciences, 2017). Evangelicals worldwide total around 600 million, with nearly 100 million in the USA (about $30 \%$ of the population of the USA) (Wikipedia, n.d.). It is more of a movement than an institution; there are thousands of independent subsets with diverse sub-beliefs, organizations, and ethnicities without direct knowledge of or connection to one another. They all share four Christian beliefs, which mark their identity: the Bible, Jesus Christ, salvation, and activism/evangelism (Anderson \& Stetzer, 2016).

Beginning with God and the Bible, there are foundational beliefs that God is eternal and sovereign, and that God created the Earth and all on the Earth. The pinnacle of God's creation is humans, who were created in God's image of rational intellect, emotion, and volition (Biblica Inc., 1973a). Since God created the Earth, he is the owner, who has delegated stewardship/management responsibility to his human creatures. We are the beneficiaries of God's creation but also accountable to God for the care of his creation (Biblica Inc., 1973b). This becomes the theological basis for Christian environmentalism-humans are responsible to God for the preservation, protection, and thriving of all God has created, including air, land, water, animals, plants, and especially our fellow humans. There are great challenges in fulfilling this calling, but the calling is to be considered an honor and a privilege to serve as agents of God.

The Bible does not start with environmental stewardship. It starts with God and is therefore theocentric. In other words, environmental stewardship is not an end in itself but grows out of who God is, what God has created, and all God has assigned for us to do in the care of his creation. Loving and serving God is always first. When Jesus was asked what our highest human responsibility is, he said, "Love the Lord your God with all your heart and with all your soul and with all your mind. This is the first and greatest commandment" (Biblica Inc., 1973c). On the basis of the primacy of God and the authority of the Bible, Christians are also called to love our fellow humans. After the first commandment to love God, Jesus added, "And the second is like it: 'Love your neighbor as yourself"' (Biblica Inc., 1973d). These core expectations of Christians did not originate with Jesus; they also are written in the Hebrew scriptures of the Old Testament (Biblica Inc., 1973e). On the basis of these principles, the moral code of Jesus in the New Testament includes care for the poor and vulnerable (Biblica Inc., 1973f).

Although not all Christians have adhered to the teachings of the Bible on the care of God's creation or the moral imperatives of Jesus on the care of the poor and vulnerable, these are foundational doctrines and expectations. As millions of Christians take these callings seriously, they are immediately challenged with prioritization. What if environmental stewardship hurts the poor? What if helping the poor hurts the environment? 
When Hurricane Maria devastated the island Commonwealth of Puerto Rico, $97 \%$ of the electrical power grid was knocked out. Transportation was curtailed; hospitals ran on diesel generators or closed; patients on ventilators or dialysis died. Puerto Rico is primarily powered by fossil fuels (U.S. Energy Information Administration, 2017). Generators and fossil fuels were shipped, airlifted, and carried to sustain human life and to improve living conditions. Of course, cataclysmic crises should not be the standard for deciding between protecting the environment from pollution and protecting human life, but, in everyday choices, decisions are often made between good competing values. Sadly, too many decide their priorities first and then unnecessarily choose to harm one and help another when options are available that will harm neither.

In 2010, Evangelical Christian leaders from 198 countries met in Cape Town, South Africa, under the auspices of the Lausanne Movement and issued the Cape Town Commitment (Lausanne Movement, 2010). Included in Part II of the lengthy Commitment is a statement on caring for God's creation and caring for the poor and suffering:

All human beings are to be stewards of the rich abundance of God's good creation. We are authorized to exercise godly dominion in using it for the sake of human welfare and needs, for example in farming, fishing, mining, energy generation, engineering, construction, trade, or medicine. As we do so, we are also commanded to care for the earth and all its creatures, because the earth belongs to God, not to us. We do this for the sake of the Lord Jesus Christ who is the creator, owner, sustainer, redeemer and heir of all creation.

We lament over the widespread abuse and destruction of the earth's resources, including its bio-diversity. Probably the most serious and urgent challenge faced by the physical world now is the threat of climate change. This will disproportionately affect those in poorer countries, for it is there that climate extremes will be most severe and where there is little capability to adapt to them. World poverty and climate change need to be addressed together and with equal urgency.

We encourage Christians worldwide to:

A) Adopt lifestyles that renounce habits of consumption that are destructive or polluting;

B) Exert legitimate means to persuade governments to put moral imperatives above political expediency on issues of environmental destruction and potential climate change;

C) Recognize and encourage the missional calling both of (i) Christians who engage in the proper use of the earth's resources for human need and welfare through agriculture, industry and medicine, and (ii) Christians who engage in the protection and restoration of the earth's habitats and species through conservation and advocacy. Both share the same goal for both serve the same Creator, Provider and Redeemer. (The Lausanne Movement, 2011)

This statement was subsequently adopted by the National Association of Evangelicals (USA) in 2015 (National Association of Evangelicals, 2015).

\section{Engaging in the Issue}

In the USA, issues related to climate change have become politically polarized, with politics often eclipsing scientific, religious, and moral teaching. Many explanations are offered to interpret this polarization, including the divide between those who 
trust government and institutions and those who do not share that trust. There are so many complex presuppositions and group identities involved that simple answers are hard to find and are often rejected, especially during a time of political transition and disruption. It is not that sources of political polarization are unimportant, but our discussion here focuses on description and possible paths to solutions.

\section{Religion Versus Science}

What Religious People Really Think, written by Elaine Howard Ecklund and Christopher Scheitle (New York: Oxford University Press), reports surveys of 10,000 Americans and interviews with nonreligious persons, religious persons, and science professionals. Funded by the John Templeton Foundation, in collaboration with the American Association for the Advancement of Science, and based at Rice University, this extensive research included questions on climate change.

Consider the breakdown of responses to just two of the many questions asked:

"Please tell me how interested you are in the following things: the environment ('Very interested')." All respondents 32.0\%; Evangelical Protestants 27.8\%; Mainline Protestants 31.2\%; Catholics 32.0\%; Jews 34.3\% (Ecklund \& Scheitle, 2018).

"The climate is changing and human actions are a significant cause of the change." All respondents 41.8\%; Evangelical Protestants 34.7\%; Mainline Protestants 41.6\%; Catholics 42.4\%; Jews 43.8\%; non-Western 55.4\%; unaffiliated, atheists, agnostics $49.9 \%$ (Ecklund \& Scheitle, 2018).

The differences are statistically significant but fall short of a majority on both questions in all groups except for adherents to non-Western religions, with $55.4 \%$ agreeing that the climate is changing with human action as a significant cause. Overall, most Americans of all religious affiliations say they are not "very interested" in the environment and they do not affirm that the climate is changing and human actions are a significant cause of the change. While it is worth noting that Evangelical Protestants are on the lower end of "very interested" in the environment and on the lower end of affirming climate change caused by human action, they are among the majority of all respondents in both categories. This indicates that raising concern and commitment on these issues relates to the majority of Americans although mostly so among Evangelical Protestants.

Ecklund and Scheitle give suggestions on how to engage different religious communities in the issues of environment and climate change. Here are a few that specifically relate to American Evangelical Protestants (because they are $30 \%$ of the US population and less likely to engage in these issues):

- Evangelicals are also more likely to say either that the climate is not changing at all or that the climate is changing but not because of human actions. So, while politics does contribute to lower levels of acceptance of the scientific consensus in climate change among evangelicals, politics does not appear to be the sole factor. So, for 
those conducting outreach to evangelical communities on this issue, the message needs to reach beyond the political issues to address the distinct faith concerns of evangelicals.

- Attitudes on climate change are also strongly influenced by factors like political ideology. Over and over, we found, particularly among evangelical Christians, that environmentalism was tied in their minds to political ideologies they want to distinguish themselves from. Evangelicals are the religious groups most likely to be suspicious of scientists, so they need to hear about climate change from voices they trust. Religious leaders can help here, making climate change action about theology not politics.

- Congregations not only can draw connections between theology and environmental care, but they also can provide opportunities for members to practice and reinforce environmentally conscious behaviors.

- Scientists can help make environmental issues more salient for religious believers by focusing on the human impacts of climate change, and religious leaders can use those impacts to provide people of faith with a religious rationale for climate change action. (Ecklund \& Scheitle, 2018)

Practical steps to address faith, poverty, suffering, human health, and the care of the Earth's environment begin with the presuppositions of faith and lead to actions based on faith.

- Faith communities may organize study groups, meeting over several weeks. Provide study guides that begin with Bible teaching on God's creation and God's call to care for his creation. Next, study Bible teachings on God's call to protect and provide for the poor, suffering, and vulnerable. Introduce information on the impacts of climate change that degrade God's creation and contribute to suffering and poverty. Provide stories of positive outcomes where the care of God's creation and mitigation of climate change contribute to human health and flourishing. Discuss individual and collective actions that fulfill the mandates of faith in the context of a changing climate.

- Provide persons of faith and communities of faith with theological and scientific information that comes from respected leaders who share their faith. Prioritize scientists who have strong faith commitments and are active in local faith communities. Utilize theologians, pastors, authors, and other known faith leaders who write and speak about the care of creation and climate change. Connecting with these trusted persons of influence from both the theological and scientific perspectives may be multisourced by engaging them as guest speakers in churches, authors of books and brochures, bloggers, and social media communicators, and also via other modes of communication. This approach builds on already established trust, which is leveraged to communicate information and specific practical calls to individual and collective action.

- Encourage grassroots decisions rather than prescribing personal or political action lists. This is not to preclude suggestions and recommendations. Stories, examples, and action ideas are powerful tools of influence. However, groups brainstorming how to act out their faith can lead to bottom-up movements that are often not possible when there is a concern over top-down external prescriptions and pressure. 


\section{Conclusions}

Interfaith dialogue on the health of people, the health of the planet, and our responsibility is most valuable and important when focused on humanitarian needs. Collaboration and cooperation are best suited to helping those suffering from floods, droughts, crop failures, famines, migration, and other cataclysmic events, regardless of the causes. When crises come to countries and communities of varied religions, all people of faith should step forward to rescue and restore together.

Interfaith dialogue and cooperation may be least valuable when one seeks to inform and persuade each religion's constituents. The lesser value is rooted in different theologies, presuppositions and historical ignorance, and lack of trust of each other's religious faith. While dialogue among leaders is frequently valued and practiced, it has minimal predictability of influence among the masses in foreseeable generations. In other words, cooperation in practical humanitarian actions is good in that it helps those in need, but the trajectory from practical meeting of needs to persuasion of differing religious groups is best accomplished unilaterally rather than multilaterally. It comes down to matters of prioritization and deployment of resources. The priority of each religious community on issues of the environment and humanitarianism and the use of resources will produce greater effects when largely focused on separate religious traditions and communities.

This most applies to the continuum from individuals and communities of faith to individuals and communities of agnostics, atheists, and the unaffiliated. The belief systems and worldviews are at such a distance that they are a substantial barrier and distraction to dialogue and collaboration on environmental concerns. The same may be said of the distance between Western and non-Western religions. However, this conclusion is less applicable to groups within Christianity. For example, many of the doctrinal presuppositions and social teachings of the Roman Catholic Church and American Evangelicalism align (e.g., cardinal Christian doctrines and prolife social teaching).

The strategies for increasing engagement and action within each religious tradition are most likely to succeed when (1) leaders give voice to those who trust them as leaders; (2) persuasion begins with the tenets of the faith and not just current events or scientific consensus; (3) environmental catastrophes dominate the news and create opportunities for engagement and persuasion (preparing plans for communication before such catastrophes occur and quickly seizing the news cycle); and (4) scientists within the faith have disproportionate influence because of their understanding and terminology of both their faith and their science. And, finally, all of this takes a long time. 


\section{References}

Anderson, L., \& Stetzer, Ed. (2016, March 2). Defining evangelicals in an election year. Christianity Today Magazine.

Biblica, Inc. The Holy Bible, New International Version ${ }^{\circledR}$, Niv ${ }^{\circledR}$ Copyright $(\odot)$ 1973a, 1978, 1984, 2011 Biblica, Inc., Genesis 1-3.

Biblica, Inc. The Holy Bible, New International Version ${ }^{\circledR}$, Niv ${ }^{\circledR}$ Copyright $@ 1973 b, 1978,1984$, 2011 Biblica, Inc., Genesis 1:27-31.

Biblica, Inc. The Holy Bible, New International Version ${ }^{\circledR}$, Niv ${ }^{\circledR}$ Copyright $\odot 1973 \mathrm{c}, 1978,1984$, 2011 Biblica, Inc., Matthew 22:37-38.

Biblica, Inc. The Holy Bible, New International Version ${ }^{\circledR}$, Niv ${ }^{\circledR}$ Copyright $\odot$ 1973d, 1978, 1984, 2011 Biblica, Inc., Matthew 22:39.

Biblica, Inc. The Holy Bible, New International Version ${ }^{\circledR}$, Niv ${ }^{\circledR}$ Copyright $\odot$ 1973e, 1978, 1984, 2011 Biblica, Inc., Deuteronomy 6:4-5 and Leviticus 19:17-18.

Biblica, Inc. The Holy Bible, New International Version ${ }^{\circledR}$, Niv ${ }^{\circledR}$ Copyright $(\odot)$ 1973f, 1978, 1984, 2011 Biblica, Inc., Matthew 25:36-44 (God's judgment), Luke 10:25-37 (Parable of the Good Samaritan) and approximately 2000 references in the Bible to advocacy and care of the poor.

Catholic Ecology. (2015, June 18). With Laudato Si, "Everything is connected". Catholic Ecology. Retrieved September 30, 2017, from https://catholicecology.net/blog/ laudato-i-everything-connected

Ecklund, E. H., \& Scheitle, C. P. (2018). Religion vs. science: What religious people really think. Oxford, UK: Oxford University Press. Chapter 6.

Hackett, C., \& McClendon, D. (2017, April 5). Christians remain world's largest religious group, but they are declining in Europe. Pew Research Center. Retrieved September 30, 2017, from http://www.pewresearch.org/fact-tank/2017/04/05/ christians-remain-worlds-largest-religious-group-but-they-are-declining-in-europe/

National Association of Evangelicals (2015). Caring for God's creation: A call to action. National Association of Evangelicals. Retrieved October 1, 2017, from https://www.nae.net/ caring-for-gods-creation/

Pontifical Academy of Sciences (2017, November 2-4). Health of people, health of planet and our responsibility. The workshop of the Pontifical Academy of Sciences, Vatican.

The Lausanne Movement (2010, October 17-24). Cape Town 2010: The third Lausanne Congress on World evangelization. Lausanne Movement. Retrieved October 1, 2017, https://www.lausanne.org/gatherings/congress/cape-town-2010-3

The Lausanne Movement (2011). The Cape Town Commitment, Section IIB, 6. The Lausanne Movement. Retrieved October 1, 2017, from https://www.lausanne.org/content/ctc/ ctcommitment

U.S. Energy Information Administration (2017, September 21). Puerto Rico. U.S. Energy Information Administration. Retrieved September 30, 2017, from https://www.eia.gov/ state/?sid=RQ

Wikipedia. (n.d.). Evangelicalism. Wikipedia. Retrieved September 30, 2017, from https:// en.wikipedia.org/wiki/Evangelicalism 
Open Access This chapter is licensed under the terms of the Creative Commons Attribution 4.0 International License (http://creativecommons.org/licenses/by/4.0/), which permits use, sharing, adaptation, distribution and reproduction in any medium or format, as long as you give appropriate credit to the original author(s) and the source, provide a link to the Creative Commons license and indicate if changes were made.

The images or other third party material in this chapter are included in the chapter's Creative Commons license, unless indicated otherwise in a credit line to the material. If material is not included in the chapter's Creative Commons license and your intended use is not permitted by statutory regulation or exceeds the permitted use, you will need to obtain permission directly from the copyright holder. 